\title{
ЗАСОБИ ФОРМУВАННЯ ЦИФРОВОЇ КОМПЕТЕНТНОСТІ МАЙБУТНІХ ВИКЛАДАЧІВ МИСТЕЦЬКИХ ДИСЦИПЛІН В ЗАКЛАДАХ ВИЩОЇ ОСВІТИ КНР
}

\begin{abstract}
Цзі Іпін
здобувач третього (освітньо-наукового) рівня вищої освіти кафедри освітології та інноваційної педагогіки, Харківський національний педагогічний університет імені Г. С. Сковороди, м. Харків, Україна
\end{abstract}

У статті визначено суть поняття «иифрова компетентність» та компоненти ії формування: мотиваційно-особистісний, когнітивний, діяльнісний та рефлексійно-оцінний. Зазначені компоненти ицифрової компетентності майбутніх викладачів мистецьких дисциплін мають формуватися з урахуванням специфіки професійної діяльності та відповідних засобів навчання.

Ключові слова: ијифрова компетентність, формування, майбутні викладачі, мистецькі дисиипліни, засоби, заклад вищої освіти, Китай.

The article defines the essence of the concept of «digital competence» and the components of its formation: motivational-personal, cognitive, activity and reflection-evaluation. These components of digital competence of future teachers of art disciplines should be formed taking into account the specifics of professional activities and appropriate teaching aids.

Key words: digital competence, formation, future teachers, art disciplines, means, institution of higher education, China.

Останнім часом як в Україні, так і в Китайській Народній Республіці гостро постає проблема підготовки майбутніх викладачів мистецьких дисциплін в закладах вищої освіти КНР, які володіють на високому рівні не лише професійною, а й цифровою компетентністю. За словами Лю Хуейцінь [2], вчитель образотворчого мистецтва повинен поєднувати в собі художника та педагога, який володіє широким арсеналом образотворчих та сучасних засобів навчання.

Професійна діяльність викладачів мистецьких дисциплін може бути ефективною, якщо його педагогічна робота постійно підкріплюється його особистим досвідом у практиці малюнка, живопису, графіки, скульптури, дизайну, декоративно-ужиткового мистецтва, його здатністю показати здобувачам освіти процес втілення художнього образу в тому чи іншому матеріалі, використовуючи різноманітні об- 
Розділ III. Історичні та порівняльні аспекти в теорії і практиці духовно-інтелектуального виховання й навчання разотворчі техніки - як традиційні, і сучасні. На важливу роль професійної діяльності у загальному розвитку особистості на засадах цифровізації вказували О. Жерновникова [1], Мей Хонг [3], О. Наливайко [4] та ін.

Успіхи в опануванні образотворчою діяльністю засобами цифровізації зумовлюють рівень як професійного, а й особистісного розвитку майбутніх викладачів мистецьких дисциплін, впливаючи на розвиток сприйняття, уяви, образного мислення, здібності сприймати різноманітні явища дійсності та давати їм оцінку з естетичних позицій, бачити прекрасне не тільки в мистецтві, а й у повсякденному цифровому житті. Без цих якостей неможлива ефективна взаємодія сучасного викладача зі студентами, яка здійснюється в цифровому освітньому просторі.

Процеси глобалізації, що йдуть у сучасній освіті, безпосередньо мають відношення і до галузі вищої художньо-педагогічної освіти. Глобалізація знаходить своє вираження не тільки в уніфікації змісту та структури вищої професійної освіти, подвійність дипломів, взаємообмін викладацькими кадрами та студентами, широкому впровадженні цифрових освітніх технологій, що дозволяють створити відкриті освітні системи, а й з розширення обміну між країнами в освітній галузі [5].

У сучасній вищій освіті поряд із глобалізацією чітко простежується прагнення збереження унікальності національних культур, що виражається в освітній галузі у напрямі опанування національними традиціями в мистецтві, в опорі на особливості естетичного сприйняття та відображення дійсності, характерні національній культурі [5].

Отже, визначена нами специфіка навчання мистецьких дисциплін, надає підстави охарактеризувати цифрову компетентність як здатність здобувача освіти постійно оновлювати в умовах удосконалення цифрових технологій сукупність компетентностей, необхідних викладачу для здійснення професійної діяльності у цифровому освітньому середовищі.

Напрацювання китайських учених (Лю Хуейцінь, Мей Хонг, Чжан Вейцзин) надають підстави стверджувати, що цифрова компетентність майбутніх викладачів мистецьких дисциплін має складатися 3 чотирьох компонентів: мотиваційно-особистісного (внутрішні та зовнішні мотиви до своєї майбутньої професійної діяльності), когні- 
тивного (сукупність теоретичних знань, умінь та навичок майбутнього викладача для ефективної організації освітнього процесу із застосуванням цифрових засобів навчання), діяльнісного (практичне втілення професійно-педагогічних знань майбутнього викладача, його інтелектуальних, пізнавальних, технічних, конструкторських та технологічних умінь, необхідних навичок для ефективного впровадження цифрових технологій в освітній процес) та рефлексійно-оцінного (здатність до аналізу та самоаналізу власної діяльності, узгодження цілей, способів та отриманих результатів, усвідомлення свого стилю діяльності, готовність до їх творчої зміни). Зазначені компоненти цифрової компетентності майбутніх викладачів мистецьких дисциплін мають формуватися з урахуванням специфіки професійної діяльності та відповідних методів.

Визначені компоненти формування цифрової компетентності майбутніх викладачів мистецьких дисциплін в закладах вищої освіти КНР доцільно формувати з використанням таких засобів навчання:

1) навчальне моделювання персонального цифрового освітнього середовища здобувачів освіти у період навчання в ЗВО за програмами вищої художньо-педагогічної освіти, у період проходження педагогічної практики, у період проходження курсів підвищення кваліфікації: використання в освітньому процесі цифрових освітніх ресурсів, а також матеріалів цифрових платформ для освіти (що містять готовий якісний цифровий освітній контент), організація спільних проєктів в онлайнсередовищах, взаємодії та педагогічного спілкування у хмарних сервісах; розвиток мережевої активності та комунікації у соціальних мережах; використання інструментарію цифрових інструментів та сервісів під час проєктування різноманітних навчальних ситуацій уроку, створення цифрового освітнього контенту;

2) підвищення кваліфікації викладачів 3 питань організації навчального процесу у цифровому освітньому середовищі, удосконалення методичної підготовки в аспекті цифрової трансформації освіти 3 використанням сучасних платформ онлайн-навчання, участі у вебінарах, веб-майстернях тощо;

3) обмін позитивним та негативним педагогічним досвідом роботи в цифровому освітньому середовищі у складі мережевих педагогічних спільнот; участь у творчих конкурсах у межах пріоритетних національних проєктів 3 цифровізації освіти, вивчення вітчизняного та 
Розділ III. Історичні та порівняльні аспекти в теорії і практиці духовно-інтелектуального виховання й навчання

зарубіжного педагогічного досвіду роботи у цифровому освітньому середовищі.

\section{Список використаних джерел:}

1. Жерновникова О., Перетяга Л., Ковтун А., Кордубан М., Наливайко, О. Наливайко Н. Технологія формування цифрової компетентності майбутніх учителів засобами гейміфікації. Інформаційні технології і засоби навчання. 2020. 75 (1). 170-185.

2. Лю Хуейцінь. Три неминучі проблеми в швидкому розвитку інформатизації освіти. Інформаційні технології освіти. Початкова і середня школа. 2008. № 10. С. 80-81 (кит).

3. Мей Хонг. Створення цифрового Китаю: використання можливості нового етапу розвитку інформатизації. Pеople's. Жэньминь жибао. 2018. Вип. 05 (кит.).

4. Наливайко О. Цифровізація освітнього середовища в закладах вищої освіти китайської народної республіки. Актуальні питання гуманітарних наук. 2020. 2(32). 188-194.

5. 郑立平; 人工智能视域下机器人学习的教育应用与创新探索 $[\mathrm{J}]$; 中国新通信; 2019 年13期. 